Сорока Марина Василівна,

викладач кафедри режисури та майстерності

актора Київського національного університету

культури і мистецтв

https://orchid.org/0000-0002-0509-8508

mvsoroka92@gmail.com

\title{
СЦЕНІЧНИЙ СИНТЕЗ МИСТЕЦТВ МОДЕРНУ
}

Мета статті - визначити синтетичні виміри культури модерну як певного комунікативного простору. Методологія дослідження грунтується на застосуванні методів аналізу наукової літератури, художньостильового аналізу творів образотворчого мистецтва 3 метою виявлення їх предметно-образного ряду i принципів формоутворення в контексті мистецьких комунікацій. Наукова новизна полягає у з'ясуванні формотворення синтетичних тенденцій стилю модерн у його сценічному просторі. Висновки. Стиль модерн має велику сцену світової культури, в якій сформувався свій неповторний синтез мистецтв. Театральність присутня архітектурі, оздобленню інтер'єрів, живопису, графіці. Всі види мистецтв на підставі стильової інваріантності взаємодіяли у спільному комунікативному просторі та у окремому сценічному ансамблі, зокрема опері, балетному мистецтві та ін.

Ключові слова: культура повсякдення, сценічний простір, стиль модерн, синтез мистецтв, модель.

Сорока Марина Васильевна, преподаватель кафедры режиссуры и мастерства актера Киевского национального университета культуры и искусств

\section{Сценический синтез искусств модерна}

Цель статьи - определить синтетические измерения культуры модерна как определенного коммуникативного пространства. Методология исследования основана на применении методов анализа научной литературы, художественно-стилевого анализа произведений изобразительного искусства с целью выявления их предметнообразного ряда и принципов формообразования в контексте художественных коммуникаций. Научная новизна заключается в выяснении формообразования синтетических тенденций стиля модерн в его сценическом пространстве. Выводы. Стиль модерн имеет большую сцену мировой культуры, в которой сформировался свой неповторимый синтез искусств. Театральность присутствует архитектуре, отделке интерьеров, живописи, графике. Все виды искусств на основании стилевой инвариантности взаимодействовали в общем коммуникативном пространстве и в отдельном сценическом ансамбле, в частности опере, балетном искусстве и др.

Ключевые слова: культура повседневности, сценическое пространство, стиль модерн, синтез искусств, модель.

Soroka Marina, teacher of the department of directing and acting skills Kyiv National University of Culture and Arts

Stage synthesis of Art Nouveau

The purpose of the article is to determine the synthetic dimensions of modern culture as a particular communicative space. The methodology of the research is based on the application of methods of analysis of scientific literature, art-style analysis of works of fine arts to identify their subject-shaped series, and principles of form formation in the context of artistic communications. The scientific novelty is to find out the structure of synthetic trends of Art Nouveau style in its stage space. Conclusions. Art Nouveau style presents the subtle principles of stylism, which combined organism, ornamentalism. The harmony of style was more hypothetical than existing. In each work, one can see how harmoniously, disharmonious, and polyphonically the realities of the world of architecture, synthesis of arts, stage synthesis are combined. Thus, the modernist I. Stravinsky, O. Benoit, M. Vrubel, M. Roerich are not remakes that are mystified and transformed into a specific heroic epic. It is an authentic outburst of the spirit of breaking the classical culture. Art Nouveau is now emerging as a modeling system that actualizes the nostalgic scene. A. Tarkovsky, at one time, was very close to modern installations of culture (eternal juvenility and absolute spirituality), which is especially noticeable in his cinematic interpretation of S. Lem's Solaris. The director dreamed of some mystical power that exists outside of practice, outside the world, beyond individual choice, beyond the courage to be. The Art Nouveau style has a vast scene of world culture, in which its unique synthesis of the arts has formed. Theatricality is present in architecture, interior decoration, painting, graphics. Based on style invariance, all kinds of arts interacted in a shared communicative space and in separate stage ensembles, in particular opera, ballet art, etc.

Key words: daily culture, stage space, Art Nouveau style, art synthesis, model.

Актуальність теми дослідження. Стиль модерн спонукав до театральних синтез різних жанрів, напрямків, стильових орієнтацій. Саме це відбулося в сезонах С. Дягілева, де на одній сцені досить

С Сорока М. В., 2019 
органічно співіснували класичні, модерні, авангардні та ретро-архаїзуючі, язичницькі, етнографічнорепрезентативні тенденції. Шедеврами декоративного мистецтва ставали блискучі декорації Н. Гончарової, М. Ларіонова, П. Пікасо, О. Бенуа та ін. Стиль модерн екзистенційно маркував образ на межі життя і смерті, де панував ерос як естетична невтаманність духу, самотність неспокійної людини кінця століття.

Аналіз досліджень та публікацій. Проблема модерних синтетичних тенденцій досліджувалася в працях Н. Барної, Ю. Легенького, Д. Сараб'янова, В. Горюнова, М. Тубли та ін. [1; 4; 5; 3]. Естетичні та культурологічні аспекти інтерпретації культури модерну як синтетичного феномена у сучасній науці вивчені вкрай недостатньо. Особливого аналізу заслуговують загальні театральні тенденції стилю та їх сценічне втілення.

Мета статті - визначити синтетичні виміри культури модерну як певного комунікативного простору.

Виклад основного матеріалу. В контексті досліджень з синтезу мистецтв, зокрема у його стильовому вимірі, протиставляються „модерн” у широкому розумінні як доба розуму та стиль модерн, який вважається останнім світовим стилем [3]. «Модерн в широкому розумінні, - зазначає Ю. Легенький, - як його вже почали розуміти в наш час, - це вся величезна планета культури, пов'язана $з$ класичним розумом, коли людина живе вірою в те, що вона $є$ Homo Sapiens. Але розум скидається з п'єдесталу і наступають інші часи. Так і поділяють ці дві великі епохи: епоху розуму й епоху безумства, умовно називаючи їх «модерн» і «постмодерн». Добре це чи погано, чорне чи біле, але до цього звикли» [4, с. 204].

Стиль модерн презентує витончені принципу стилізму, де поєднувалися організмізм, теургізм, орнаменталізм. Гармонія стилю була більш гіпотетичною, ніж наявною. В кожному творі можна побачити, наскільки гармонійно, дисгармонічно та поліфонічно поєднується реалії світотворення архітектури, синтезу мистецтв, сценічного синтезу.

Якщо поглянути на дім Рябушинського як синтез мистецтв, який здійснив Ф. Шехтель, то можна стверджувати, що саме в ньому живуть і театр, і сцена, тут можна побачити своєрідні алюзії Візантії, образи Сходу, вплив творчості Й. Ольбриха. Образ такого модерного симбіозу став душею будинку. Вітраж стелі явно відбиває шотландський імпульс, композитна колона зі сріблястим завершенням на другому поверсі нагадує про архітектуру ранньої античності.

«Цікаво, що улюблена квітка стилю модерн - лілея в християнській іконографії пов’язувалась 3 Дівою Марією. Якщо Діва Марія закликала до себе людину, то вона вмирала. Так, у глибині всіх глибин, в основі всіх цих лілей, трав, води, русалок, текучості орнаменту лежить танатос, перетворення через ерос, через надрив індивідуального космічного еротизму, який сповіщав про якусь одвічну смерть людства. Смерть виглядала як вічна осінь у дивному золотому вбранні іiі кольорів, в дивних орнаментах Клімта, в дивному пір'ї павичів, яких зображував М. Врубель, у дивній орнаментальності як такій, котра знаходила цю бездомність як кінець всьому і найбільш суттєвим чином», - зазначає Ю. Легенький [4, с. 217]. Стиль модерн стає образом діяльності Ф. Шехтеля, А. Гауді, В. Городецького, У. Морріса, М. Врубеля, В. Сєрова, В. Борисова-Мусатова.

«Жар-птиця» - один із цікавих шедеврів хореографії Михайло Фокіна, де декорації Олександра Головіна, костюми Олександра Головіна і Бакста вражають своєю різноманітністю і проривом у дохристиянське світло язичницького світу. Декорація Головіна «Кащеево царство», 1910 рік, - це суцільна гра дорогоцінних мінералів, які накладаються нібито на полотно. Так в динаміці дискретного мозаїчного цілого оживає нова Візантія, новий потік світлоносної глибини модерну, випромінюючи просторовість світів, які важко собі уявити у цьому світі. Це і протобрази Гауді, це і якісь ритмоформи які знов-такі асоціюються з архітектурою Гауді, і водночас - це натуралістичні відсилки до воріт і дерев, які перетворюються на тотальний орнамент, що находить відлуння в небі, в орнаментальному русі хмар.

Коли ми поглянемо на образи, які здійснив Вацлав Ніжинський („Заполудяний відпочинок фавна” а також образ „Синього бога”), то можна стверджувати, що це своєрідна пластика неоміфу, неомодерних інтерпретацій, де сама постать губиться в хмарах часу.

Рання робота Л. Бакста «Елізіум», пано за античними мотивами для драматичного театру Віри Комісаржевської у Санкт-Петербурзі, 1906 рік, - це ухід у якийсь давній хаос, чорну пастку небуття. Зелено-фіолетовий колорит з ритмами вертикалей руїни, вічного світу античності свідчить про те, що це руйна культури, руйна модерну, яка символізує дух стилю модерн. Силует Іди Рубінштейн на полотні Валентина Сєрова нагадує давньоєгипетський ієрогліф. Фактично - це скульптура, бо вона створена із тла полотна. Тло і тіло людини визначається лише пластично, тло починається i 
завершується напівкосмічними плавними уходами в глибину, а тіло вібрує в майже в танцювальному ритмі силуету-ієрогліфу.

Героїні твору В. Борисова-Мусатова «Водойма» (панно, що зараз знаходиться у Третьяковській галереї, 1902) ходять біля якогось сумного озера с заплаканими очима, як демони М. Врубеля, які не раді тому, що з'явилися на цей світ. Цей своєрідний театр біля озера є якийсь язичницький, дохристиянський, нагадує видово дивних феєрій А. Ватто і О. Бенуа. У творах В. Борисова-Мусатова біля водойм збираються в сірому тумані дами 3 кринолінами, 3 чудовими силуетами, що наче розчиняються в грубому полотні мішковини. Простір картини є дивним, орнаментальним, графічним, вібрує і резонує інші стилі. Це не готика, не ренесанс, не візантійський стиль. Це симбіоз усіх означених культурних образів. В архітектурній теорії ці стилі прописуються як еклектика. Втім стиль модерн не $є$ маньєристичною ознакою культуротворчості, а $\epsilon$ певним стильовим імпульсом (готичним, ренесансним, барочним), акумулює всі стилі на правах композитної єдності.

Модерні інтенції підхопили митці авангарду. Дилема авангарду та модерну є надзвичайно гострою. Саме модерн здійснив деструкцію класичної культури, хоча здійснив ії імпліцитно, в надрах формотворення як звернення до біоніки і тієї полістилістики, яка і досі примушує добудовувати останній храм А. Гауді. Найважливішим $є$ те, що еклектика вже несла в собі модерн, адже несла його в інших формах, інших імплікаціях, ніж тих, що модерн здійснив пізніше. Так, модерн у широкому значенні як модернізм, тобто доба розуму, змінюється на добу новітньої міфології постмодерну. Отже, дихотомія «модерн-постмодерн» залишається надзвичайно абстрактною моделлю світобачення. Щоб зрозуміти красу «Свадєбки» І. Стравінського, красу його «Петрушки», красу модерних імплікацій Н. Гончарової, М. Ларіонова, безкінечність чудових варіативних світів Л. Бакста, а також скіфську мову «Половецьких плясок», декорації до яких виконав М. Реріх, щоб відчути простір сучасного аранжування половецького стану, потрібно реконструювати стиль модерн як тотальний симбіоз культури, тотальний обрій зондування надр землі і безодні неба.

Звернення до старих фото, до тих костюмів, які оживають в галогенному друці - це своєрідні інсталяції самої часовості, що свідчать про стиль модерн як дзеркало того екрану культури, що дійшов до нас так дивно і в таких складних умовах. Коли ми дивимся на портрет Сергія Прокоф' єва, написаний Наталією Гончаровою, то не віриться, що за цим академічним листом стоїть такий буйний темперамент, який визначився в іiі декоративних натюрмортах, декоративних пано у сценічній роботі для театральних вистав. Несподівано розкривається талант Сергія Лифаря, який зробив портрет Сергія Дягілєва пунктиром великого формату 150 на 150 см. У декоративній манері ми чітко впізнаємо особистість, впізнаємо модерні імплікації, що походять від Матісса і вже тяжіють до постмодернізму. Рожеві губки бантиком, висвітлюється лише один правий монокль. Білий шматок волосся свідчить про сивину, яка маркує статуру принца.

Інакшими є інтонації стилю модерн у Г. Нарбута, що наслідує стилістику І. Білібіна. Усі майстри модерну близькі до тієї стилістики, яку можна назвати неовізантійською, можна назвати еклектикою, що тяжіє до неокласики, українського бароко і до інших полістилічних синтез, які живуть в українському модерні, але існує одна комунікативна сцена модерну.

Можна стверджувати, що мистецький синтез модерну в більшій мірі тяжіє до нерефлективності первинної міфології, а також шукає нову множинність образів, де саме бачення синтезу мистецтв вмонтовано у творчість і створює епіцентр стилю модерн. Стильова синтетична реальність задається як індивідуалізм пошуку, як знаходження свого «Я» на перетині всіх інших можливих «Я», зустрінутих в космологічному просторі культури.

I. Стравінський зазначав: «Я розглядаю свій талант як божий дар. Я завжди молився і молився йому, просив змоги застосувати його. Коли в ранньому дитинстві я відкрив, що завдяки опікуну маю музичні здібності, я дав йому клятву постійно розвивати їх» [6]. Далі він пише, що дзеркало - це інструменти пам'яті, і в ньому бачиш себе швидше таким, яким був, ніж яким є зараз. І. Стравінський згадує, що М. Реріх приїхав у Париж навесні, але майже не був зацікавлений Францією і після прем’єри поїхав у Росію. Більше його ніколи не бачили [6].

Д. Сараб'янов стверджував, що у 20-ті, 30-ті роки лише деякі історики мистецтва вивчали стиль модерн. У загальній картині розвитку мистецтвознавчої думки їх роботи не зайняли належного місця, справжне відкриття модерну почалося в 50-ті роки, коли почали цікавитися стилем модерн, відбувалися виставки, присвячені або окремим видатним майстрам модерну, або стилю в цілому. «Після достатньо тривалого панування строгої функціональної архітектури, авангардного живопису, що реалізували себе в абстракціонізмі або в сюрреалізмі, новітні інтенції модерну вже в просторі постмодерної культури пробудили спогад про надлишковий естетизм, загадковість образів, символів, 
про красу предметного середовища, що оточує людину. Незважаючи на те, що модерн перестав функціонувати як стиль, до нього звертаються як до вічної минувшини, омріяної ностальгійними спонуками. Культура повсякдення на стиль модерн захопила частково і 70-ті роки XX століття, але потім спала, затихла, з'явилась можливість поглянути на модерн інакше, означити його досягнення, слабкість та розібратися в тих перспективах, які він відкривав» [5, с. 11].

Однак $є$ інші погляди на стильові формотворення. Так, англійський дослідник архітектури і дизайну Л. Бхаскаран стверджує, що модерн ніколи не зникав з арени формотворення XX століття [2].

Отже, модерн І. Стравінського, О. Бенуа, М. Врубеля, М. Реріха - це не римейк, що містифікуються і перетворюються на певну героїчну епопею. Це автентичне виборювання духу за доби зламу класичної культури. Зараз виникає модерн як моделююча система, що актуалізує сцену ностальгійного типу. А. Тарковський свого часу був дуже близький до модерних інсталяцій культури (вічної ювенальності та абсолютної духовності), що особливо помітно в його кінематографічній інтерпретації «Соляриса» С. Лема. Режисер мріяв про якусь містичну силу, яка існує поза практикою, поза світом, поза людським виборюванням, поза мужністю бути.

Висновки. Проблема синтезу і дилема авангарду і модерну, їх діалогу залишається надзвичайно гострою. Криза класичного мистецтва відбулась не в футуризмі, не в авангарді, в вже у модерні. Саме модерн здійснив деструкцію класичної культури, хоча здійснив іiі імпліцитно, в надрах формотворення як звернення до тої біоніки і тої формотворчої полістилістики, яка у Гауді і досі примушує добудовувати його останній храм як сучасне диво сучасного архітектурного світу Барселони. Отже, полістилістика, стильовий поліфонізм визначаються у стилі модерн як симбіоз, а потім він вже підхоплюється в 60-ті роки такими постмодерними діячами, як Р. Вентурі та ін. Саме в модерні зароджується постмодерний еклектизм, що згодом стає концептуальним формотворчим полісвітом, полісценізмом.

\section{Jimepamypa}

1.Барна Н. В. Дизайн у контексті художньої культури XX-XXI століть. Київ : «Університет «Україна», 2015. $353 \mathrm{c}$.

2. Бхаскаран Л. Дизайн и время / пер. с. англ. И.Г. Голыбиной. Москва : АРТ-РОДНИК, 2007. 256 с.

3. Горюнов В. С., Тубли М. П. Архитектура эпохи модерна. Санкт-Петербург : Стройиздат, 1992.360 с.

4. Легенький Ю. Г. Философия моды ХХ столетия. Київ : КНУКіМ, 2003. 300 с.

5. Сарабьянов Д. В. Модерн. История стиля. Москва : Галарт, 2001. 344 с.

6. Стравинский И. Диалоги. URL: rumagic.com/ru_zar/sci_philosophy/stravinskiy/

\section{References}

1. Barna, N. V. (2015). Design in the Context of Art Culture of the XX-XXI Centuries. Kyiv: "Ukraine University" [in Ukrainian].

2. Bhaskaran, L. (2007). Design and time, trans. from. English I.G. Golybina. Moscow: ART SPRING [in Russian].

3. Goryunov, V. S., Tubli, M. P. (1991). Architecture of the modern era. St. Petersburg: Stroyizdat, 1992 [in Russian].

4. Legenky, Yu. G. (2003). Fashion philosophy of the twentieth century. Kiev: KNUKiM [in Russian].

5. Sarabyanov, D. V. (2001). Modern. History of style. Moscow: Galart [in Russian].

6. Stravinsky, I. (2001). Dialogues. URL: rumagic.com/ru_zar/sci_philosophy/Stravinskiy [in Russian].

Стаття надійшла до редакиії 28.09.2019 р. 